\title{
Kesebandingan Pidana Uang Pengganti dan Pengganti Pidana Uang Pengganti dalam Rangka Melindungi Hak Ekonomis Negara dan Kepastian Hukum ${ }^{1}$
}

\author{
Fontian Munzil, Imas Rosidawati Wr., dan Sukendar \\ Universitas Islam Nusantara Bandung \\ Jl. Soekarno Hatta No 530, Bandung, Jawa Barat \\ fontian@mail.com
}

\begin{abstract}
Corruption Law should arrange for replacement of the convicted criminal money to be paid to the state. Legally if the convicted person is not able to reimburse the state, it will be replaced with imprisonment. Substitute criminal restitution imposed is not proportional to the amount of money obtained by the convict from the state and in addition, there is a wide disparity of restitution between many convicts. This study examines, first, what kind of additional criminal punishment in the form of payment of compensation which can protect the economic rights of the people? Second, how is the concept of proportionality (proportionality) should be applied for criminal compensation against the accused of corruption in the future? This study is normative juridicial, which uses methods of comparative law and conceptual. The results found that: first, the payment of compensation in practice does not protect the lost economic rights of the people through the passage of time until the decision is legally enforceable; payment of compensation is based only on the amount that the defendant obtained as proceeds of corruption. Secondly, the concept of proportionality/ proportionality substitute for criminal compensation can be applied with Jurimetri approach.
\end{abstract}

Keywords: Crime, money substitutes, corruption.

\begin{abstract}
Abstrak
UU Tipikor mengatur pidana uang pengganti kepada terpidana yang harus dibayarkan kepada negara. Secara yuridis jika terpidana tidak mampu mengembalikan uang negara, maka akan diganti dengan pidana penjara. Pengganti pidana uang pengganti yang dijatuhkan tidak sebanding dengan besarnya uang negara yang diperoleh terpidana dan di samping itu terjadi disparitas yang lebar antar terpidana. Penelitian ini mengkaji, pertama, bagaimanakah penjatuhan pidana tambahan berupa pembayaran uang pengganti menjangkau perlindungan hak ekonomis masyarakat? Kedua, bagaimanakah konsep kesebandingan (proporsionalitas) pengganti pidana uang pengganti terhadap terdakwa korupsi di masa depan. Penelitian ini merupakan penelitian yuridis normatif, yang menggunakan metode perbandingan hukum dan konseptual. Hasil penelitian menemukan: Pertama, pembayaran uang pengganti dalam praktik tidak melindungi hak ekonomis masyarakat yang hilang dengan berjalannya waktu sampai dengan putusan berkekuatan hukum tetap, pembayaran uang pengganti hanya didasarkan pada jumlah yang diperoleh terdakwa hasil tindak pidana korupsi. Kedua, konsep kesebandingan/proporsionalitas pengganti pidana uang pengganti dapat diterapkan dengan pendekatan Jurimetri.
\end{abstract}

Kata Kunci : Pidana, uang pengganti, korupsi

${ }^{1}$ Hasil Penelitian Unggulan Institusi yang dibiayai oleh Dikti melalui DIPA Kopertis Wilayah IV Jawa Barat, Kementerian Pendidikan dan Kebudayaan, Tahun Anggaran 2014. 


\section{Pendahuluan}

Undang-Undang Nomor 20 Tahun 2001 tentang Perubahan Atas UndangUndang Nomor 31 Tahun 1999 tentang Pemberantasan Tindak Pidana Korupsi dalam Pasal 18 ayat (1) huruf b mengatur tentang pembayaran uang pengganti yang jumlahnya sebanyak-banyaknya sama dengan harta benda yang diperoleh dari tindak pidana korupsi. Pasal tersebut merupakan bentuk pidana tambahan yang dapat dijatuhkan kepada terdakwa korupsi. Pidana pokok yang disertai dengan pidana tambahan tersebut khusus pada Pasal 2 dan Pasal 3 UU Tipikor yang dalam unsur deliknya menyebutkan tentang merugikan keuangan negara atau perekonomian negara.

Penjatuhan pidana tambahan tersebut merupakan salah satu cara untuk mengembalikan kondisi keuangan negara pada keadaan semula dan memberikan penjeraan langsung kepada akibat kejahatan korupsi yang dilakukannya. Efek jera berupa penghukuman secara umum diterapkan atas dua aspek, yakni atas diri pelaku dalam ruang lingkup individu dan efek jera yang dapat diterapkan dalam ruang lingkup yang umum. ${ }^{2}$

Tujuan utama dari penghukuman/dampak bagi pelaku antara lain: ${ }^{3} 1$. kepemilikan atas hak kebendaan dan kenyamanan pelaku; 2. kebebasan/kemerdekaan bertindak atas aktifitas pelaku; 3. reputasi atau status sosial pelaku; 4. hubungan/interaksi sosial pelaku; 5. spiritual dan kesejahteraan pelaku.

Ahli ekonomi modern seperti Richard Posner, melihat hukuman sebagai bentuk suatu mekanisme pemulihan. ${ }^{4}$ Lembaga hukum harus berfungsi maksimal dan memiliki pertimbangan dan ukuran yang sama dalam penjatuhan hukuman kepada terdakwa korupsi agar memberikan efek jera dan menciptakan kepastian hukum.

UU Tipikor mengatur bahwa terdakwa korupsi akan dijatuhi pengganti pidana uang pengganti berupa tambahan pidana penjara, jika tidak mampu

2 Christopher Harding, Richard W. Ireland, Punishment Rhetoric, Rule, and Practise, First Published, Routledge, New York USA, hlm. 118

${ }^{3}$ I bid., hlm. 186 hlm. 76

${ }_{4}^{4}$ Andrew Ashworth, Sentencing and Criminal Justice, Cambridge University Press, Fifth Edition, UK, 2010, 
mengembalikan uang negara. L.R. Huesmann dan C.L. Podolski menyatakan, bahwa hukuman mungkin memiliki beberapa peran yang tepat dalam hal pengelolaan perilaku (behaviour management) tetapi harus diterapkan dengan cara yang bijaksana. ${ }^{5}$ Secara teoritis sebagian masyarakat setuju bahwa hukuman meningkatkan kepatuhan dan menekan perilaku antisosial hanya untuk periode yang singkat pasca hukuman tersebut diterapkan. ${ }^{6}$

Penjatuhan pidana penjara pengganti pidana uang pengganti secara konsisten antar terdakwa, adalah bentuk perwujudan kepastian hukum dan pertimbangan untuk menjatuhkan pengganti pidana uang pengganti yang tinggi dapat diberikan batasan minimal dan maksimal, agar memberikan penjeraan dan sekaligus menutup peluang bagi para terpidana untuk memilih pengganti pidana penjara daripada memilih mengembalikan uang negara. Pelaku tindak pidana korupsi melihat bahwa akibat suatu pelanggaran hukum adalah sebagai risiko, bukannya melihat dari sisi akibat hukum yang harus diterima, dengan demikian sisi untung ruginya secara matematis ekonomis menjadi pertimbangan utama untuk melakukan tindak pidana korupsi. Penentuan batas minimal dan maksimal terhadap pengganti pidana uang pengganti berupa tambahan pidana penjara, harus menggunakan parameter yang terukur dengan persepsi yang sama antar penegak hukum, misalnya dengan mempertimbangkan kedudukan, keberadaan dan kontribusi terdakwa dalam suatu tindak pidana korupsi.

Korupsi merupakan kejahatan luar biasa yang merusak nilai-nilai sosial masyarakat secara bertahap dan mengambil hak ekonomis negara. Hak ekonomis negara adalah hak secara ekonomi yang harus diperoleh akibat adanya kegiatan berupa pembangunan di bidang perekonomian oleh negara, yang akan menghasilkan nilai tambah secara ekonomis bagi negara. Nilai tambah secara ekonomis misal pengadaan sarana publik seperti pasar atau pembangunan infrakstruktur seperti jalan umum. Masyarakat luas harus mendapatkan perlindungan agar haknya tidak hilang akibat perbuatan korupsi tersebut. Nilai ekonomis yang akan diciptakan negara secara langsung atau tidak langsung demi kepentingan masyarakat luas akan menjadi tertunda/hilang akibat perbuatan

${ }^{5}$ L.R. Huesmann and C.L. Podolski, Punishment:a Psychological Perspective (The Use of Punisment edited by Sean McConville), First Published, Willan Publishing, Oregon, USA, 2003, hlm.77

${ }^{6}$ Ibid 
tindak pidana korupsi. Terlepas dari biaya yang besar akibat dari tindak pidana dan ancaman kejahatan terjadi di masyarakat, hal yang mendasar dari rasionalitas dari tindak pidana adalah tidak melakukan minimalisasi biaya sosial yang timbul akibat tindakan pidana. ${ }^{7}$

Penjadwalan pembayaran uang pengganti yang disebutkan dalam UU Tipikor dalam waktu sebulan, yang kemudian pada tahap berikutnya adalah penyitaan aset terpidana, tidak tertuang dengan jelas waktu yang dibutuhkan untuk menyelesaikan pencarian/pelacakan asetnya terpidana dan waktu yang dibutuhkan untuk melakukan proses pelelangan aset tersebut pasca aset terpidana dapat diperoleh oleh negara. ${ }^{8}$ Penentuan batas waktu proses pencarian aset terpidana untuk pengembalian uang negara, seharusnya ditentukan rentang waktu proses penyelesaian pengembalian uang negara tersebut, agar negara segera mendapatkan dana tersebut untuk melakukan pembangunan serta memberikan kepastian hukum bagi terpidana.

Metoda Jurimetri dapat diaplikasikan/diterapkan terhadap pidana uang pengganti dalam kondisi sebagai berikut: a. ketidakmampuan terpidana mengembalikan secara penuh; $b$. kemampuan terpidana mengembalikan sebagian dengan cara bertahap; c. kemampuan terpidana mengembalikan dengan cara mencicil; d. kemampuan terpidana mengembalikan secara kombinasi yaitu bertahap dan mencicil.

Jurimetri dipusatkan pada tiga masalah salah satunya adalah penggunaan metode kuantitatif dalam pelaksanaan hukum termasuk di dalamnya penggunaan statistik, model matematik dan simulasi. ${ }^{9}$ Jurimetri yang pertama kali digunakan pada 1949, maksudnya adalah penggunaan metode ilmiah dalam bidang hukum. Metode ilmiah tersebut terutama adalah ilmu pasti dan logika atau dengan pernyataan yang lebih umum, penelaahan secara kuantitatif terhadap aspek-aspek dari problema-problema yuridis. ${ }^{10}$

7 Mario J. Rizzo, Economic Cost, Moral Costs or Retributive, The Cost of Crime (editor Charles M. Gray), Volume 12, Sage Publication, Inc, Londong, England, 1979, hlm. 277

8 Pasal 18 ayat (2), UU No. 31 Tahun 1999 sebagaimana telah diubah dengan UU 20 Tahun 2001 tentang Pemberantasan Tindak Pidana Korupsi.

${ }^{9}$ Ronny Hanitijo, Metode Penelitian Hukum dan Jurimetri, Cetakan Keempat, Ghalia Indonesia, Jakarta, 1990, hlm. 135

${ }^{10}$ Ibid., hlm. 138 
Metoda Jurimetri juga dapat diaplikasikan/diterapkan dengan tujuan sebagai berikut: a. pengganti pidana uang pengganti berupa hukuman penjara agar konsisten; b. menentukan batas minimal dan maksimal pengganti pidana uang pengganti dengan kategori khusus para pelaku. Penjatuhan pidana layak menggunakan pedoman/petunjuk, misalnya berupa tabulasi agar terjadi konsistensi antar hakim dan memberikan kepastian hukum bagi para terdakwa dan menghindari disparitas yang lebar antar terdakwa. Hakim adalah bagian yang paling penting dalam proses penciptaan disparitas terhadap hukuman, diharapkan sebagian besar hakim menolak keberadaan kesenjangan yang tidak beralasan, respon lainnya adalah pernyataan yang mempertanyakan kompetensi profesional mereka terkait dengan dispartitas tersebut. ${ }^{11}$

Perhitungan penambahan pidana uang pengganti berupa memperhitungkan nilai bunga, merupakan pemikiran yang rasional mengingat hak keekonomian negara yang hilang yang secara langsung dan tidak langsung akan menimbulkan efek ekonomis yang berkelanjutan. UU Tipikor menyebutkan, jika terpidana tidak membayar uang pengganti paling lama 1 bulan sesudah putusan pengadilan yang telah memperoleh kekuatan hukum tetap, maka harta bendanya dapat disita oleh jaksa dan dilelang untuk menutupi uang pengganti tersebut. Jika harta benda tidak mencukupi untuk membayar uang pengganti, maka dipidana dengan pidana penjara yang lamanya tidak melebihi ancaman maksimum dari pidana pokoknya sesuai dengan ketentuan dalam Undangundang ini dan lamanya pidana tersebut sudah ditentukan dalam putusan pengadilan. ${ }^{12}$

Pengganti pidana uang pengganti berupa tambahan pidana penjara yang dijatuhkan kepada terdakwa akibat ketidakmampuan terdakwa mengembalikan uang negara dianalisis aspek kesebandingannya antara penjatuhan pidana dibandingkan dengan besarnya uang negara yang diperoleh oleh terdakwa. Pidana penjara sebagai pengganti pidana uang pengganti tidak mengandung ukuran yang konsisten antara satu perkara dengan perkara lain, sehingga

\footnotetext{
${ }^{11}$ Julian V. Roberts, Sentencing Trends and Sentencing Disparity (Making sense of sentencing edited by Julian V. Roberts and David P. Cole, University of Toronto Press,Canada, 1999, hlm. 149.

12Pasal 18 ayat (3), UU No 31 Tahun 1999 sebagaimana telah diubah dengan UU 20 Tahun 2001 tentang Pemberantasan Tindak Pidana Korupsi
} 
disparitas yang lebar berpotensi terjadi dan menimbulkan potensi bagi terpidana untuk memilih tambahan pidana penjara ketimbang mengembalikan uang negara yang dikorupsi.

\section{Rumusan Masalah}

Berdasarkan uraian tersebut di atas, dirumuskan permasalahan dalam penelitian ini sebagai berikut. Pertama, bagaimanakah penjatuhan pidana tambahan berupa pembayaran uang pengganti menjangkau perlindungan hak ekonomis masyarakat? Kedua, bagaimanakah konsep kesebandingan (proporsionalitas) pengganti pidana uang pengganti terhadap terdakwa korupsi di masa depan?

\section{Tujuan Penelitian}

Adapun tujuan dari penelitian ini adalah, pertama, mengetahui penjatuhan pidana tambahan berupa pembayaran uang pengganti menjangkau perlindungan hak ekonomis masyarakat. Kedua, mengetahui konsep kesebandingan (proporsionalitas) pengganti pidana uang pengganti terhadap terdakwa korupsi di masa depan.

\section{Metode Penelitian}

Penelitian ini menggunakan metode pendekatan yuridis normatif, yaitu hukum dikonsepsikan sebagai norma/kaidah. Metode perbandingan hukum, dan hukum yang akan datang digunakan untuk mempertajam kajian terkait dengan Tipikor. Teknik pengumpulan data berupa studi kepustakaan dilakukan melalui tahapan-tahapan penelitian dengan mengumpulkan data sekunder yang menggunakan bahan hukum primer, sekunder dan tersier. Wawancara dilakukan secara mendalam sebagai data pelengkap. Spesifikasi penelitian adalah deskriptif analisis untuk memberikan data seteliti mungkin tentang suatu kondisi. Seluruh 
data dianalisis secara yuridis kualitatif kemudian diuraikan dan disajikan secara terstruktur agar dapat dilakukan analisis.

\section{Hasil Penelitian dan Pembahasan}

\section{Pembayaran Uang Pengganti Dikaitkan dengan Upaya Perlindungan Hak Ekonomis Masyarakat}

Pembayaran uang pengganti merupakan pidana tambahan dalam undangundang korupsi di Indonesia. ${ }^{13}$ Pidana Tambahan tidak dapat dijatuhkan tersendiri tetapi dijatuhkan bersama-sama dengan pidana pokok. Pembayaran uang pengganti merupakan upaya untuk memulihkan kondisi keuangan negara seperti keadaan semula atas kerugian negara atau perekonomian negara yang tercipta akibat tindak pidana korupsi. Pembayaran uang pengganti adalah penjatuhan pidana tambahan terhadap terdakwa tipikor yang disebutkan dalam Pasal 18 UU ayat (1) huruf b bersamaan dengan penjatuhan pidana pokok pada Pasal 2 dan Pasal 3 UU Tipikor. Pelanggaran hukum pada Pasal 2 dan Pasal 3 UU Tipikor tersebut didominasi pada perkara pengadaan barang dan jasa yang ditujukan untuk membangun perekonomian secara langsung atau tidak langsung.

Aktor lainnya dalam hal pembayaran uang pengganti adalah memasukkan perhitungan nilai waktu uang (time value of money) yang mana hasil perhitungan tersebut setelah ditambahkan dengan kerugian negara yang harus dibayar, diharapkan akan sebanding dengan kehilangan nilai ekonomis pembangunan oleh negara pada kurun waktu tersebut.

Teori pembalasan sering dicirikan sebagai suatu pertanggungjawaban pembenaran penghukuman yang melihat pada kondisi/situasi masa lalu yang mana hal ini berlawanan dengan teori pencegahan, dan juga reformasi teori, yang benar-benar melihat ke masa depan. ${ }^{14}$ Pencegahan dapat juga dilakukan secara tidak langsung dengan memberikan penjeraan, yang mana efek tersebut dapat efektif terhadap pihak yang berpotensi atau berniat melakukan suatu tindak

13 Pasal 18 ayat (1) huruf b, UU No. 31 Tahun 1999 sebagaimana telah diubah dengan UU 20 Tahun 2001 tentang Pemberantasan Tindak Pidana Korupsi.

14 Ted Honderich, Punishment, The Supposed Justifications, Cambridge, USA, 1989, hlm. 51 
pidana. Wright dan Walgrave mengatakan, bahwa penghukuman adalah pemberian penderitaan yang disengaja yang dijatuhkan oleh penegak hukum. Sementara itu, Daly dan Duff mengatakan, bahwa hukuman adalah sebagai sesuatu yang dianggap oleh pelaku menjadi beban. Di samping itu, pengertian lainnya oleh Barton dan Dignan, adalah mengadopsi gagasan yang sangat luas/lebar bahwa hukuman sebagai setiap tindakan yang dikenakan pada pelaku. ${ }^{15}$

Teori pembalasan menurut peneliti dapat diartikan/dimaknai sebagai bentuk konsekuensi yang diberikan oleh negara yang berlandasan hukum, yang telah mengatur suatu akibat hukum dan yang tidak kalah penting adalah kesesuaian/kesebandingan antara perbuatan dan hukuman yang dijatuhkan. Hukuman didefinisikan implikasinya sebagai penderitaan dari perlakuan yang keras oleh otoritas negara kepada seseorang atas kesalahannya dalam menghormati hukum. ${ }^{16}$ Perhitungan kerugian uang negara harus dihitung secara rinci dengan mempertimbangkan rentang waktu sampai dengan uang negara tersebut dapat dikembalikan oleh terpidana korupsi. Proses penyelidikan, penyidikan, penuntutan hingga proses di pengadilan berpotensi menghabiskan waktu yang lama sampai dengan tingkat kasasi apalagi jika tindak pidana tersebut baru terungkap setelah beberapa tahun kemudian. Uang negara yang dikorupsi oleh terdakwa dalam rentang waktu (proses hukum) tersebut menjadikan uang/dana negara tersebut menjadi sia-sia, terutama terhadap tindak pidana yang baru dimulai penyidikannya setelah beberapa lama terjadi. Penggantian kerugian uang negara dalam rentang waktu tersebut diilustrasikan seolah-olah dana tersebut disimpan/diinvestasikan di Bank/lembaga keuangan lainnya, dimana secara praktis dana tersebut akan berkembang dengan adanya penambahan yang bersumber dari perhitungan unsur bunga. Perhitungan kerugian uang negara dengan cara memperhitungkan tingkat suku bunga Bank (time value of money) berupa nilai kompensasi, akan memberikan keadilan kepada masyarakat dimana hak kenikmatan ekonominya tertunda akibat tindak pidana korupsi tersebut. hlm. 25

15 Ibid.

${ }^{16}$ Joel Feinberg, The Expressive Function of Punishment, State University of New York Page, Albany, 1972, . 25 
Perhitungan pengembangan uang negara dalam kurun waktu tertentu, dihitung karena uang memiliki nilai waktu yang dapat menggandakan nilai uang tersebut (compounding) atau yang disebut dengan penggandaan yang terjadi seiring dengan berjalannya waktu. Compounding adalah proses menentukan nilai sejumlah uang sekarang pada masa yang akan datang. ${ }^{17}$ Ilustrasi tentang perhitungan bunga majemuk dapat dilihat pada tabel berikut:

Tabel 1: Ilustrasi Perhitungan Time Value of Money

\begin{tabular}{|c|c|c|c|}
\hline $\begin{array}{c}\text { (Tahun Ke) } \\
\text { Year }(t)\end{array}$ & $\begin{array}{c}\text { Present value (PV) } \\
\text { Dana Awal } \\
\text { Dalam Rupiah }\end{array}$ & $\begin{array}{c}\text { Interest Assumption (r) } \\
\text { (suku bunga asumsi) } \\
\text { Dalam Persen (\%) }\end{array}$ & $\begin{array}{c}\text { Future Value (FV) } \\
\text { (dana masa depan) } \\
\text { Dalam Rupiah }\end{array}$ \\
\hline 0 & Rp. 3.000 .000 .000 & $9 \%$ & Rp. 3.270.000.000 \\
1 & Rp. 3.270 .000 .000 & $9 \%$ & Rp. 3.564.300.000 \\
2 & Rp. 3.564 .300 .000 & $9 \%$ & Rp. 3.885.087.000 \\
3 & Rp. 3.885 .087 .000 & $9 \%$ & Rp. 4.234 .744 .830 \\
4 & Rp. 4.234 .744 .830 & $9 \%$ & Rp. 4.615 .871 .865 \\
5 & Rp. 4.615 .871 .865 & $9 \%$ & Rp. 5.031 .300 .333 \\
6 & Rp. 5.031 .300 .333 & $9 \%$ & Rp. 5.484.117.362 \\
\hline
\end{tabular}

Sumber: Diolah Sendiri

Perhitungan dengan rumus keuangan sederhana dapat dilakukan dengan cara sebagai berikut: 18

$\mathrm{FVt}=\operatorname{Po}(1+\mathrm{r})^{\mathrm{t}}$

$\mathrm{FVt}=$ Nilai dana dimasa depan pada tahun ke $\mathrm{t}$.

Po $=$ Nilai awal dana pada awal tahun ke 1 .

$\mathrm{r} \quad$ = Besarnya suku bunga yang menjadi patokan/rujukan.

$\mathrm{t}=$ Tahun (lamanya dana dikembangkan).

Contoh perhitungannya (pada tabel di atas) sebagai berikut: Rp. 3.000.000.000,00 x $(1+0,09)^{6}=$ Rp. 5.484.117.362 dimana :

Rp. 3.000.000.000,00 adalah nilai dana awal pada awal tahun pertama.

Angka 1 adalah angka baku.

0.09 adalah suku bunga sebesar $9 \%$ p.a. (asumsi suku bunga Bank).

Angka 6 adalah jangka waktu/lamanya dana tersimpan selama 6 tahun.

Rp. 5.484.117.362 adalah hasil pengembangan dana pada tahun ke 6.

Tabel di atas menunjukkan jika kerugian uang negara yang terjadi pada saat itu sebesar Rp. 3.000.000.000,00 dan akhirnya sampai dengan putusan

\footnotetext{
${ }^{17}$ Robert C. Higgins, Analisis Manajemen Keuangan, Edisi Kedua, Indira, 1996, hlm 245

18 Brigham \&Houston, Fundamentals of financial Management Dasar-Dasar Manajemen Keuangan, Buku 1, Edisi 10, Salemba Empat, Jakarta, 2004, hlm. 281-283
} 
pengadilan baru berkekuatan hukum tetap setelah 6 tahun kemudian, maka dana yang akan terbentuk di masa yang akan datang (tahun ke 6) menjadi Rp. 5.484.117.362, dimana jumlah tersebut yang menjadi hak negara untuk dikembalikan, dengan merujuk suku bunga 9\% pertahun sebagai dasar perhitungan pengembangan dana. Jika negara hanya merujuk dengan angka awal yaitu Rp. 3.000.000.000 maka kelebihan dana yang terbentuk sebesar Rp. 5.484.117.362- Rp. 3.000.000.000= Rp. 2.484.117.362 yang menjadi hak negara akan hilang.

Dana lebih yang terbentuk sebesar Rp. 2.484.117.362 merupakan nilai kompensasi ekonomis negara yang hilang akibat dana tersebut di korupsi. Tingkat suku bunga 9\% disebut sebagai tingkat biaya kesempatan (opportunity cost rate) atau tingkat pengembalian yang dapat dihasilkan dari investasi alternatif. ${ }^{19}$ Tingkat bunga dapat mengacu/merujuk terhadap suku bunga pasar yang wajar dan layak pada saat delik tersebut terjadi, hal tersebut dengan pemikirkan bahwa dana tersebut dapat diinvestasikan dalam investasi produk keuangan perbankan yang akan jumlahnya akan meningkat akibat adanya perhitungan bunga bank.

Konsep nilai waktu dari uang berhubungan dengan tingkat bunga yang digunakan dalam perhitungan aliran kas dimana nilai uang saat ini (present value) akan berbeda dengan nilai uang tersebut di waktu yang akan datang (future value) karena adanya faktor bunga. ${ }^{20}$ Future value disebut juga dengan compound value yang menggunakan compound interest dalam perhitungannya dimana compound interest (bunga berganda) digunakan dalam perhitungan untuk menentukan berapa besar penerimaan untuk suatu (n) tahun yang akan datang atas deposit sekarang (initial principal) berdasarkan tingkat bunga tertentu. ${ }^{21}$ Perhitungan bunga majemuk adalah perhitungan yang menambahkan bunga pada dana awal dan dibungakan kembali, sehingga hasil yang akan didapat menjadi lebih besar lagi karena pengalinya adalah dana pokok awal ditambah dengan bunga yang telah terbentuk sebelumnya. Penentuan dana yang akan dihitung dengan mengenakan unsur bunga harus disepakati apakah dana yang diperoleh oleh

${ }^{19}$ Ibid., hlm. 287

${ }^{20}$ Martono, D. Agus Harjito, Manajemen Keuangan, Cetakan kedelapan, Ekonisa, Yogyakarta, 2010, hlm. 20

21 Syafaruddin Alwi, Alat-alat Analisis dalam Pembelanjaan, Andi Offset Yogyakarta, Edisi Revisi, Yogyalarta, 1994, hlm. 150 
terpidana atau besarnya kerugian negara yang nyata terjadi berdasarkan hasil audit dari pejabat yang berwenang. Perhitungan di atas adalah bentuk konsistensi dan konsekwensi terhadap pemberantasan korupsi sesuai dengan spirit korupsi sebagai kejahatan luar biasa sehingga seluruh penanganan pidana korupsi dari depan hingga akhir (front to end) ditangani dengan pola pikir atau ide dan caracara yang luar biasa.

Prinsip bahwa penghukuman kepada seseorang dapat dibenarkan secara moral jika kondisi berikut terpenuhi:22 1 . memang dapat menghasilkan efek pencegahan; 2. tidak ada hukuman lain yang dapat mencegah secara efektif dengan biaya dan tekanan yang rendah. Hukuman yang memenuhi kondisi ini disebut dengan pencegahan ekonomis atau hukuman yang dapat mencegah secara ekonomis. Teori ini sesuai dengan pengenaan pada hukuman tambahan dengan metode time value of money yang dapat memberikan efek pencegahan yang bersifat represif ekonomis.

Praktiknya pengembalian kerugian negara berpotensi dikembalikan secara bertahap yang mana tahap pertama adalah pembayaran sebagian dan sisanya tahap kedua dengan cara mencicil. Perhitungan dengan skema pembayaran pidana uang pengganti dengan cara bertahap, diilustrasikan dengan perhitungan sebagai berikut: a. pidana uang pengganti sebesar Rp. 2.000.000.000,00; b. pembayaran tahap pertama sebesar $50 \%$ yaitu Rp. $1.000 .000 .000,00$, sisanya dicicil selama 2 tahun pada tahap ke 2; c. putusan yang telah berkekuatan hukum tetap setelah 2 tahun kemudian.

Tabel 2: Perhitungan Pembayaran Tahap Pertama

\begin{tabular}{|c|c|c|c|}
\hline $\begin{array}{c}\text { Tahun Ke) } \\
\text { Year }(\mathrm{t})\end{array}$ & $\begin{array}{c}\text { Present value (PV) } \\
\text { Dana Awal }\end{array}$ & $\begin{array}{c}\text { Interest Assumption (r) } \\
\text { (suku bunga asumsi) }\end{array}$ & $\begin{array}{c}\text { Future Value (FV) } \\
\text { (dana masa depan) }\end{array}$ \\
\hline 0 & Rp. 1.000 .000 .000 & $9,00 \%$ & Rp. 1.090 .000 .000 \\
1 & Rp. 1.090 .000 .000 & $9,00 \%$ & Rp. 1.188 .100 .000 \\
2 & Rp. 1.188 .100 .000 & $9,00 \%$ & Rp. 1.295 .029 .000 \\
\hline
\end{tabular}

Ilustrasi pada tabel 2 adalah perhitungan secara matematis dengan menggunakan perhitungan time value of money. Pidana uang pengganti yang harus dibayar oleh terpidana korupsi dengan kondisi perkara telah berkekuatan

${ }^{22}$ Ibid., hlm. 59 
hukum tetap setelah 2 tahun kemudian, sejak tindak pidana tersebut terjadi adalah sebesar Rp. 1.295.029.000.

Alternatif perhitungan lainnya secara matematis atas pembayaran tahap kedua dengan cara mencicil secara bulanan misal kerugian negara Rp. 2.000.000.000,00 adalah sebagai berikut:

1. Nilai dana awal: Rp. 2.000.000.000,00

2. Suku bunga asumsi: $9 \%$ p.a.

3. Jangka waktu mencicil: 2 tahun=24 bulan

Besarnya cicilan adalah sebagai berikut: ${ }^{23}$

1. $\mathrm{PMT}=\mathrm{FV} \times((\mathrm{i} /(\mathrm{A}-1))$

2. $2.000 .000 .000 \times 0,09 /\left((1+0,09)^{2}-1\right)=\operatorname{Rp} .91 .369 .484,56$

Besarnya cicilan pertahun adalah Rp. 91.369.484,56, jika dibayar secara bulanan maka cicilan perbulan adalah Rp. 91.369.484,56/12=Rp. 7.614.124 yang wajib dicicil oleh terpidana korupsi. Masalah yang akan timbul di kemudian hari adalah jika terpidana ditengah waktu/periode mencicil tersebut, tidak sanggup membayar lagi sehingga sesuai dengan putusan pengadilan yang telah berkekuatan hukum tetap, akan diganti dengan pidana penjara. Perhitungan pidana penjara yang harus dijalani akibat ketidakmampuan terpidana membayar cicilan tersebut dapat dihitung secara proporsional atas sisa pokok/sisa pidana uang pengganti yang belum terbayar. Sisa pokok/Sisa pidana uang pengganti dapat dilihat pada tabel cicilan yang tercantum besarnya sisa pokok setiap bulannya. Perhitungan matematis di atas mencerminkan kepastian hukum dan keadilan bagi dan keadilan bagi terpidana yang beritikad untuk mengembalikan uang negara yang diperoleh dari hasil tindak pidana korupsi.

Konsep restorative justice dari aspek keekonomian negara akan terwujud seiring dengan penerapan konsep tersebut di atas. Restorative justice dalam Black law Dictionary disebutkan bahwa Resorative Justice adalah sanksi alternatif atas kejahatan yang memfokuskan pada perbaikan kerugian yang telah dilakukan, untuk memenuhi kebutuhan korban, dan menahan pelaku bertanggung jawab 
atas perbuatannya. ${ }^{24}$ Restorative Justice adalah suatu proses dimana para pihak yang memiliki kepentingan atas suatu pelanggaran yang spesifik dan kolektif, untuk mengatasi dan bagaimana menghadapi pelanggaran itu dan implikasinya untuk masa depan. ${ }^{25}$

Pengembalian dana negara dengan perhitungan dengan pendekatan time value of money, menurut peneliti adalah bentuk dari pendekatan restorative justice dengan maksud mengembalikan/memulihkan seluruh kerugian negara seutuhnya kepada kondisi awal berserta kehilangan waktu/tertundanya secara ekonomis pembangunan nasional, dengan memperhitungkan dan menambahkan unsur bunga sesuai metoda time value of money. Kelemahan dan hambatan untuk penerapan restorative justice antara lain adalah orang yang kaya dapat membayar ganti kerugian sedangkan orang miskin tidak dapat. ${ }^{26}$

Sanksi yang bersifat restoratif yang akan dijatuhkan/dikenakan harus secara luar biasa/tegas, dalam rangka memberikan ruang saling menghormati antara para pihak, perbedaannya yang sangat kecil antara restoratif dan penghukuman sehingga terminologi yang digunakan adalah sanksi restoratif daripada menggunakan terminologi penghukuman. ${ }^{27}$ Korupsi melestarikan ketidaksetaraan obyektif yang dilakukan dengan dua cara, korupsi menyebabkan adanya perampasan yang mengakibatkan adanya ketimpangan kekayaan dan hak pribadi yang akhirnya dapat mengancam kepentingan-kepentingan yang ada. Kedua cara tersebut dapat dilakukan dengan berbagai bentuk korupsi. ${ }^{28}$

Pendekatan Jurimetri diterapkan di Kanada oleh Komisi Penghukuman pada 1970, yang telah mengenalkan proposal yang menuju pada strukturisasi putusan mengenai hukuman penjara, apakah sesuai dengan pidana yang dilakukan. Proposal tersebut adalah perubahan yang cepat dan signifikan yang mana hal tersebut merupakan respon/tanggapan atas persepsi komisi sebagai

${ }^{24}$ Black Law Dictionary, New Edition (Ninth Edition by Bryan A. Garner), West, Publishing Co,USA, 2004, hlm. 1428

25 Andrew Ashworth, Is Restorative Justice The Way Forward for Criminal Justice (Restorative Justice Critical Issues Edited by Eugene McLaughlin, Ross Fergusson, Gordon Hughes, Louise Westmarland), First Published, Sage Publication, London 2003, hlm. 164 hlm. 116

${ }^{26}$ Syaiful Bakhri, Perkembangan Stelsel Pidana Indonesia, Cetakan 1, Total Media, Yogyakarta, Oktober 2009,

27 Jolien Willemsens, Restorative Justice: A Discussion of Punishment (Repostioning Restorative Justice edited by Lode Walgrave), First Published Willan Publsihing Culmcott House, UK, 2003, hlm. 41

${ }^{28}$ Peter M. Ward, Corruption Development and Inequality, First Published, Routledge, London, 1989, hlm. 20 
ketidakjelasaan terhadap aturan penghukuman yang berjalan selama ini. Petunjuk/pedoman termasuk kualitatif dan kuantitatif dituangkan dalam formulir pedoman, yang mana setiap kategori dari suatu pelanggaran, apakah memenuhi syarat pidana atau tidak, jika memenuhi syarat maka secara relatif rentang pidana penjara yang sesuai dengan pedoman pemindanaan tersebut tidak jauh berbeda (sempit). ${ }^{29}$ Teori ini dapat diterapkan pada tabel perhitungan time value of money yang diterapkan pada setiap tingkat peradilan dengan maksud agar Hakim dapat dengan mudah menentukan hukuman pengganti pidana uang pengganti sesuai dengan tindak pidana tersebut tersebut dan penerapan time value of money dapat terwujud jika Jaksa mengajukan tuntutannya dalam berkas perkara terdakwa.

Beberapa negara melakukan upaya untuk meminimalisir perbedaan antar putusan pengadilan adalah dengan cara membuat suatu pedoman yang dapat dijadikan rujukan bagi hakim dalam hal menjatuhkan sanksi pidana yang mana ide tentang penjatuhan pidana yang proporsional menjadi ide yang berkembang yang menjadi gagasan untuk membuat suatu pedoman pemidanaan yang mampu mereduksi subyektifitas hakim dalam memutus perkara. ${ }^{30}$ Secara empirik, hasil dari sentralisasi birokrasi dan profesionalitas dalam sistem pidana modern telah mampu mengatasi dan cukup efektif terhadap kebanyakan pelanggar hukum. ${ }^{31}$

Netherland memiliki program yang disebut dengan law enforcement communication untuk melakukan sosialisasi terhadap suatu pelanggaran misal pelanggaran pidana lingkungan hidup. Sosialisasi tersebut mencakup lamanya pidana penjara yang akan pelanggar hukum terima atas suatu pelanggaran hukum. ${ }^{32}$ Penegak hukum di Netherland memiliki kesepakatan dalam menentukan rentang hukuman dengan menggunakan pedoman atas suatu pelanggaran pidana untuk menghindari disparitas yang lebar dalam penjatuhan hukuman. Hakim tetap independent/mandiri dalam menjatuhkan putusan terhadap suatu perkara pidana di Netherland, dan jika Hakim menjatuhkan

${ }^{29}$ Austin Lovegrove, Judicial Decision Making, Sentencing Policy, and Numerical Guidance, R.R. Donnelley \& Sons, Melbourne, Australia, 1989, hlm. 23 38

${ }^{30}$ Eva Achjani Zulfa, Pergeseran Paradigma Pemidanaan, Cetakan ke 1, Lubuk Agung, Bandung, 2011, hlm.

${ }^{31}$ David Garland, Punishment and Modern Society, The University of Chicago Press,USA, 1990, hlm. 183

32 Closing Interview Prof Wim Huisman, Criminalogist Lecturer, VU Amsterdam, Law School, Netherland 30 September 2014 
hukuman di luar batas yang telah ditentukan maka hakim tersebut harus dapat menjelaskan alasan atau pertimbangan yang mendasarinya, selama dalam proses eksaminasi tersebut diperoleh alasan yang tidak tepat/relevan maka hal tersebut akan dapat menunjukkan kualitas hakim yang bersangkutan, berdasarkan interview yang dilakukan terhadap Wim Huisman di VU University, Amsterdam, Netherland. Wim Huisman sebagai ahli kriminalogi, selanjutnya mengatakan bahwa faktor lain yang menjadi pertimbangan dalam menentukan rentang hukuman adalah dengan melihat kesamaan perkara pidana yang terjadi. Informasi berupa data base tentang rentang hukum yang telah diputus oleh hakim sebelumnya dapat diakses secara on line oleh para hakim dengan maksud yang sama yaitu keadilan dengan memperhatikan disparitas yang mungkin terjadi.

Kendala penjatuhan pembayaran uang pengganti dalam rangka menyelesaikan keuangan negara pernah diungkapkan Ramelan adalah:33 a. kasus korupsi dapat diungkapkan setelah berjalan dalam waktu yang kurun alam sehingga sulit untuk menelusuri uang atau hasil kekayaan yang diperoleh dari korupsi; b. dengan berbagai upaya pelaku korupsi telah menghabiskan uang hasil atau mempergunakan/mengalihkan dalam bentuk lain termasuk mengatasnamakan nama orang lain yang sulit terjangkau oleh hukum; c. adanya pihak ketiga yang menggugat pemerintah atas barang bukti dalam rangka pemenuhan pembayaran uang pengganti.

Barda Nawawi Arief mengatakan, bahwa strategi kebijakan pemidanaan dalam kejahatan-kejahatan yang berdimensi baru harus memperhatikan hakekat permasalahannya jika permasalahannya lebih dekat dengan masalah di bidang perekonomian dan perdagangan maka lebih diutamakan penggunaan pidana denda atau semacamnya. ${ }^{34}$ UU Tipikor Indonesia telah mengakomodasi hukuman penjara dalam pidana pokok termasuk pidana denda dan hukuman tambahan berupa pengganti pidana uang pengganti yang bersifat ekonomis seperti yang dinyatakan oleh Barda Nawawi Arief.

${ }^{33}$ Efi Laila Kholis, Pembayaran Uang Pengganti Dalam Perkara Korupsi, Cetakan Pertama, Solusi Publishing, Jakarta, April 2010, hlm. 15

34 Ibid., hlm. 16 
Pembebanan besaran pembayaran uang pengganti dalam perkara korupsi ada dua yaitu:35 a. model penyertaan dengan cara membebankan kerugian dengan tanggung renteng apabila salah satu mengganti kerugian negara maka pihak lain gugur kewajibannya; b. model proporsional dengan cara menghitung tanggung jawab masing-masing terdakwa berdasarkan kontribusi terdakwa dalam tindak pidana korupsi.

Penentuan pertimbangan/faktor terhadap penjatuhan pidana meliputi pengganti pidana uang pengganti, dapat dibagi dengan penggolongan pelaku itu sendiri, misal digolongkan berdasarkan sebagai berikut:36 a. jabatan atau kedudukan sosial si pelaku yang disebut dengan high profile offender dan penggolongan lainya medium and low profile offender; $b$. bentuk tindak pidana tersebut masuk pada suatu delik tertentu misal korupsi dana dibedakan dengan gratifikasi.

Peneliti beranggapan penggolongan high profile offender dapat meliputi golongan pejabat eksekutif, yudikatif dan legislatif pada lembaga negara, sedangkan medium profile offender dapat seperti pegawai negara eselon 2 ke bawah dan sebagainya, sedangkan low profile offender seperti pihak pihak swasta yang terkait dengan tindak pidana korupsi tersebut. Elaborasi posisi yang masuk dalam penggolongan tersebut dapat dijabarkan lebih lanjut. Pihak swasta yang terkait dengan bagian dari pelaku tindak pidana korupsi bersama-sama dengan pejabat publik atau penyelenggara negara, apakah pihak swasta tersebut melakukannya karena kemauan alami atau dalam tekanan/diperas oleh penyelenggara negara akan dikaji lebih detail dan mendalam dalam tulisan lainnya.

Pengembalian keuangan negara oleh terpidana dalam bentuk apapun yang menjadi kewenangan jaksa dengan kedudukannya sebagai eksekutor dapat diambil alih oleh suatu badan yang memiliki kewenangan khusus untuk memonitor seluruh recovery asset negara setelah putusan pengadilan berkekuatan hukum tetap. Badan khusus ini diperlukan untuk menjaga/mencegah adanya penyimpangan atas hasil asset tracing/pelacakan aset terpidana untuk memenuhi

${ }^{35}$ Efi Laila Kholis, Op. Cit., hlm. 20

36 Closing Interview Prof Wim Huisman, Criminalogist Lecturer, VU Amsterdam, Law School, Netherland 30 September 2014. 
pengembalian kerugian negara secara maksimal, karena akhirnya jika tidak mencukupi maka terpidana akan mendapatkan tambahan hukuman pidana penjara.

\section{Konsep Kesebandingan Pengganti Pidana Uang Pengganti Terdakwa Korupsi di Masa Depan}

Kebijakan pidana (penal policy), sebagaimana kebijakan publik pada dasarnya harus merupakan kebijakan yang rasional yang mana salah satu ukuran rasionalitas kebijakan pidana antara lain dapat dihubungkan dengan masalah efektivitas, sehingga ukuran rasionalitas diletakan pada masalah keberhasilan atau efektivitas pidana itu dalam mencapai tujuannya. ${ }^{37}$ Efektivitas pidana penjara dapat ditinjau dari dua aspek pokok tujuan pemindanaan yang terdiri dari aspek perlindungan masyarakat dan aspek perbaikan pelaku.

Pemberi hukuman mengharapkan di masa depan apapun efek yang dihasilkan dapat mengatur para pelanggar hukum, dan hal tersebut juga dapat memberikan pandangan kepada masyarakat lainnya tentang penjatuhan hukuman tersebut. Efek yang kebanyakan diharapkan adalah pencegahan dan pendidikan. ${ }^{38}$ Tipe pencegahan antara lain adalah: ${ }^{39}$ a. pencegahan yang sempurna adalah dimana individu telah menahan diri sepanjang hidupnya dari berbagai jenis tindak pidana tertentu; $b$. pencegahan secara terbatas adalah pembatasan jenis tindak pidana tertentu oleh seseorang selama beberapa periode; c. pencegahan khusus adalah sebagai kelalaian yang melampaui batas atau pembatasan dari beberapa jenis tindak pidana oleh seorang individu selama periode.

Ruang lingkup perlindungan masyarakat adalah antara lain adalah:40 a. menyelesaikan konflik. b. mendatangkan rasa aman, memperbaiki

${ }^{37}$ Barda Nawawi, Bunga Rampai Kebijakan Hukum Pidana, Cetakan Ketiga Edisi Revisi, Citra Aditya Bakti, Bandung, 2005, hlm. 224

38 Nigel Walker, Nicola Padfield, Sentencing Theory, Law and Practise, Butterworths, Second Edition, London, Dublin \& Ediburgh, 1996, hlm. 96

${ }^{39}$ Jack P. Gibbs, Crime Punishment and Deterrence, Elsevier Scientific Publishing Company, Inc, New York, 1975, hlm. 32

40 Dwidja Priyatno, Sistem Pelaksanaan Pidana Penjara di Indonesia, Cetakan Kedua, Refika Aditama, Bandung, Oktober 2009, hlm. 82 
kerugian/kerusakan. c. memperkuat kembali nilai yang hidup didalam masyarakat.

Hakikat pidana penjara menurut hakim adalah untuk melindungi masyarakat, sementara itu dua orang hakim mengatakan untuk memperbaiki pelaku kejahatan sementara itu dua orang hakim lainnya mengatakan untuk melindungi masyarakat dan memperbaiki pelaku kejahatan. ${ }^{41}$ Pedoman yang telah dikembangkan oleh Komisi Hukuman AS, yang mulai berlaku tahun 1987 adalah hukuman paling kontroversial dan dicerca dalam sejarah AS yang mana mereka umumnya dikritik mengenai hal-hal alami antara lain sebagai berikut: ${ }^{42} 1$. aspek kebijakan (terlalu membatasi kebijakan pengadilan dan terlalu memberikan keleluasaan yang luas kepada jaksa); 2. aspek teknokratis (terlalu rumit/rigid dan sulit untuk diterapkan secara akurat); 3. aspek keadilan (dengan hanya melihat satu elemen dari suatu pelanggaran dan keyakinan sebelumnya, mereka mensyaratkan bahwa para terdakwa yang sangat berbeda menerima hukuman yang sama).

Penyelesaian pengganti pidana uang pengganti berupa tambahan hukuman penjara, dalam praktiknya terpidana lebih memilih melaksanakan tambahan pidana penjara yang dianggap lebih menguntungkan dari pada membayar uang penggantinya. ${ }^{43}$ Persepsi hukuman sebagai tambahan berubah dari waktu ke waktu, seiring dengan perubahan perilaku dari nilai seseorang, kehidupan pribadi dan kualitas kejujuran. ${ }^{44}$

Dampak dari disparitas pemidanaan akan mengancam upaya penegakan hukum itu sendiri, dalam pandangan sosiologis masalah ini dipahami sebagai suatu fenomena ketidakadilan (legal injustice) yang akan mengganggu rasa keadilan masyarakat (social justice), karena kesan negatif dan menurunnya tingkat kepercayaan masyarakat pada lembaga penegakan hukum menyebabkan kontrol sosial dalam masyarakat menjadi lemah yang akhirnya muncul ketidakadilan

41 Petrus Irwan Panjaitan, Chairijah, Pidana Penjara Dalam Perspektif Penegak. Hukum Masyarakat dan Narapidana, Terbitan Pertama, Jakarta, 2008, hlm. 72

42 Michael Tonry, Judges and Sentencing Policy (Sentencing, Judicial Discretion and Training edited by Colin Munro, Martin Wasik), Sweet \& Maxwell, London, 1992, hlm. 139-140

${ }^{43}$ Efi Laila Kholis, Op.Cit., hlm. 32

${ }^{44}$ Francis Pakes, Comparative Criminal Justice, Willan Publishing, USA, 2004, No Page. 
(fairness,) ketidakberpihakan (impartiality) dan kebebasan (independency) dari lembaga peradilan. ${ }^{45}$

Ilustrasi penjatuhan pidana tambahan berupa pengganti pidana uang pengganti jika terpidana tidak dapat mengembalikan uang negara hasil korupsi yang telah berkekuatan hukum tetap adalah sebagai berikut:

\begin{tabular}{|l|l|}
\hline \multicolumn{1}{|c|}{$\begin{array}{c}\text { Pidana Uang Pengganti } \\
\text { (dalam Rupiah) }\end{array}$} & \multicolumn{1}{c|}{$\begin{array}{c}\text { Pengganti Pidana Uang } \\
\text { Pengganti (dalam Tahun) }\end{array}$} \\
\hline s/d Rp.100.000.000,- & 1 tahun \\
>Rp.100.000.000,- s/d Rp.200.000.000,- & 2 tahun \\
>Rp.200.000.000,- s/d Rp.500.000.000,- & 4 tahun \\
>Rp.500.000.000,-s/d Rp.1.000.000.000,- & 6 tahun \\
>Diatas Rp.1.000.000.000,- & 8 tahun \\
\hline
\end{tabular}

Sumber : Diolah sendiri oleh Peneliti

Pendekatan Jurimetri akan menghasilkan kepastian hukum antara satu terpidana dengan terpidana lainnya dalam hal pengganti pidana uang pengganti. Pendekatan ini akan meminimalisir disparitas pengganti pidana uang pengganti. Pendekatan ini telah diperkenalkan sejak tahun 1970 dengan menggunakan dalildalil sebagai berikut:46 1. prinsip pendekatan penjatuhan hukuman, harus menekankan pada penerapan penghukuman yang tepat atau sesuai; 2. harus menekankan pada keadilan; 3. penghukuman harus wajar/sesuai dengan sanksi yang dijatuhkan kepada pelanggar hukum/pelaku.

Disparity dalam Black's Law Dictionary adalah perbedaan yang nyata dalam kuantitas atau kualitas antara dua hal atau di antara banyak hal. ${ }^{47}$ Pendekatan secara proporsionalitas terhadap penjatuhan hukuman adalah versi yang telah diformulasikan dalam bentuk baru dalam sistem peradilan pidana.

Proporsionalitas sendiri, bagaimanapun juga menghasilkan perlindungan atas ketidakadilan jika hal tersebut muncul dikemudian hari, meskipun jangkauan undang- undang yang dibuat oleh legislator dipengaruhi arah politik, dengan implementasi kasus-perkasus sehubungan dengan karakter hakim yang

${ }^{45}$ Eva Achjani Zulfa, Op.Cit., hlm. 37.

${ }^{46}$ Andrew von Hirsch \& Andrew Ashworth, Proportionate Sentencing Eploring the Principles, First Published, Oxford University Press, New York, October 2005, hlm. 9

${ }^{47}$ Henry Campbell Black, Black's Law Dictionary, West Group, 1991, USA, hlm. 326 
bergantung pada diri hakim dalam hal menggunakan hak diskresinya. ${ }^{48}$ Esensi dari proporsionalitas dari model keadilan adalah:49 1 . kesebandingan hukuman atas kejahatan; 2. kejelasan hukuman; 3. akhir dari proses hukum dan kebebasan administrasi; 4. akhir dari disparitas (perbedaan) hukuman; 5. perlindungan hak melalui proses hukum.

Pendekatan proporsionalitas dapat diterapkan dua cara, kebanyakan yuridiksi prinsip proporsionalitas digunakan untuk menentukan batas atas (plafon) pada tingkatan suatu hukuman, sehingga penerapannya dapat dibatasi. Hal ini memberikan ruang kebebasan dalam penerapan hukumyang telah ditentukan batasannya, namun dalam operasionalnya dengan faktor-faktor yang relevan seperti seperti rehabilitasi dan keadaan pribadi seorang pelaku, hukuman dapat dikurangi. ${ }^{50}$ Ketegasan proporsionalitas dalam hal pengaturan tingginya hukuman tergantung pada berbagai prinsip dan tujuan yang sesuai dan relevan dengan hukuman. ${ }^{51}$

Prinsip proporsionalitas mengatur bahwa penderitaan atas suatu sanksi harus sama dengan keseriusan pelanggaran yang dilakukan. Konsep ini telah terbukti sulit untuk diimplementasikan/diterapkan. Ada dua alasan utama untuk hal tersebut, pertama, tidak ada apresiasi yang nyata, atas faktor apa yang relevan terhadap keseriusan suatu pelanggaran. Bahwa ini semata-mata hanya diukur dengan mengacu/merujuk pada tingkat kesusahan yang disebabkan oleh suatu pelanggaran. Kedua, tidak ada metode untuk memastikan beratnya hukuman. ${ }^{52}$

Proporsionalitas/Kesebandingan atas pengganti pidana uang pengganti dapat diterapkan jika pembayaran pidana uang pengganti dikembalikan sebagian atau tidak mencukupi. Pengganti pidana uang pengganti akan dihitung dengan pendekatan Jurimetri sehingga terpidana nantinya tidak perlu menjalankan secara penuh pengganti pidana uang pengganti karena pengembalian kerugian negara sebagian akan diperhitungkan sebagai pengurangan pengganti pidana uang pengganti secara proporsional.

${ }^{48}$ Hyman Gross, Crime and Punishment, Oxford University Press, Newyork, 2012, hlm. 53

${ }_{49}$ Barbara Hudson, Justice Through Punishment, First Published, Macmillan Education, London, 1987, hlm.

50 Mirko Bagaric, Punishment and Sentencing a Rational Approach, First Published, Cavendish Publishing Limited, Unite Kongdom, 2001, hlm. 23

51 Ibid., hlm. 25

${ }^{52}$ Ibid 
Ilustrasinya pembayaran sebagian pengganti pidana uang pengganti adalah sebagai berikut:

\begin{tabular}{|c|c|c|c|}
\hline $\begin{array}{l}\text { Pidana Uang } \\
\text { Pengganti } \\
\text { (Rupiah) }\end{array}$ & $\begin{array}{l}\text { Pengganti } \\
\text { Pidana } \\
\text { Uang } \\
\text { Pengganti } \\
\text { (Bulan) }\end{array}$ & $\begin{array}{l}\text { Pengembalian } \\
\text { sebagian } \\
\text { Pidana Uang } \\
\text { Pengganti } \\
\text { (Rupiah) }\end{array}$ & $\begin{array}{c}\text { Kesebandingan/Proporsionalitas } \\
\text { Pengganti Pidana Uang } \\
\text { Pengganti } \\
\text { (Bulan) }\end{array}$ \\
\hline Rp. 100.000.000,- & 24 Bulan & Rp. 50.000.000,- & $\begin{array}{l}(50.000 .000 / 100.000 .000) \\
* 24 \text { Bulan = 12 Bulan }\end{array}$ \\
\hline Rp. 200.000.000,- & 48 Bulan & RP. 125.000.000,- & $\begin{array}{l}(75.000 .000 / 200.000 .000) \\
* 48 \text { Bulan = } 18 \text { Bulan }\end{array}$ \\
\hline Rp. 400.000.000,- & 72 Bulan & Rp. 300.000.000,- & $\begin{array}{l}(100.000 .000 / 400.000 .000) \\
* 72 \text { Bulan = 18 Bulan }\end{array}$ \\
\hline Rp. 800.000.000,- & 96 Bulan & Rp. 350.000.000,- & $\begin{array}{l}(450.000 .000 / 800.000 .000) \\
* 96 \text { Bulan= 54 Bulan }\end{array}$ \\
\hline
\end{tabular}

Sumber: Diolah Sendiri Oleh Peneliti

Ilustrasi Tabel di atas menunjukkan bahwa pendekatan proporsionalitas/kesebandingan dalam kolom pengganti pidana uang pengganti dapat diterapkan dengan memperhitungkan pembayaran pidana uang pengganti yang dikembalikan oleh terpidana secara tidak penuh/sebagian, dan besaran dana pidana uang pengganti akan menjadi pengurang pengganti pidana uang pengganti secara proporsional.

Discretionary power atau kebebasan yang dimiliki oleh hakim dianggap sedemikian besarnya sehingga yang terjadi adalah abuse of power yang berujung kepada kesewenang-wenangan menjatuhkan hukuman, yang mana pedoman pemidanaan dianggap sebagai jalan yang terbaik dalam membatasi kebebasan hakim sehingga obyektifitas dan konsistensi dalam memutuskan perkara akan tetap terjaga. ${ }^{53}$ Diskresi adalah kekuatan/kewenangan yang diberikan kepada seseorang dengan kewenangannya untuk memilih antara dua atau lebih alternatif yang mana masing-masing alternatif tersebut berkekuatan hukum. Sussman menyatakan bahwa diskresi adalah kebebasan untuk memilih berbagai kemungkinan solusi yang berbeda, maka diskresi pada ruang lingkup hukum 
adalah kewenangan secara hukum yang diberikan kepada hakim untuk memilih berbagai alternatif yang mana seluruh pilihannya memiliki kekuatan hukum. ${ }^{54}$

Diskresi adalah kewenangan yang tidak memaksa atau memaksa dalam hal cara dan waktu tertentu atau perluasan kewenangan tersebut yang dibebankan oleh penerima kewenangan tersebut. Kewenangan tersebut untuk melakukan sesuatu atau tidak melakukan sesuatu dalam melakukan tindakan tertentu. ${ }^{55}$

Hakim dapat menggunakan hak diskresinya berupa penerapan terobosan dalam, pertimbangan keadilan ekonomis bagi negara dengan menggunakan pendekatan Jurimetri dengan perhitungan secara proporsionalitas, dengan harapan pidana tambahan yang dijatuhkan kepada terdakwa berupa pembayaran kembali uang negara dapat maksimal diterima negara karena keadilan terpidana dengan mengembalikan kerugian negara sebagian diperhitungkan secara proporsional atas pengganti pidana uang penggantinya. Penerapan secara proporsionalitas bukan merupakan tindakan abuse of power karena pada dasarnya Hakim dapat memilih atau menentukan hukuman yang pas/sesuai bagi terdakwa dalam perkara korupsi yang merupakan kejahatan bersifat luar biasa sehingga penanganannya harus dengan ide yang luar biasa pula.

Efek jera adalah salah satu dari beberapa alasan-alasan hukuman yang rasional yang mana dapat digambarkan sebagai bentuk akibat hukum/konsekwensi, dalam arti kelihatan untuk efek pencegahan. Sebenarnya efek jera/pencegahan hanyalah merupakan bentuk suatu metode yang memiliki kemungkinan untuk mencegah terjadinya tindak pidana. ${ }^{56}$ Tiga strategi penjatuhan sanksi pidana yang dikembangkan di beberapa negara di dunia adalah: ${ }^{57}$ 1. intermediate sentence adalah penjatuhan pidana berdasarkan pada satu satuan waktu yang pasti misal dipidana paling sedikit menjalani 3 tahun dan paling lama 6 tahun sehingga lama menjalani waktu tersebut tergantung narapidana; 2. determinate sentence adalah keterikatan hakim dalam menjatuhkan pidana didasarkan pada ketentuan adanya satuan waktu yang pasti oleh UU; 3.

\footnotetext{
${ }^{54}$ Aharon Barak, Judicial Discretion, Yale University Press, USA,1987, hlm. 7

${ }^{55}$ Henry Campbell Black, Op. Cit., hlm. 322

${ }^{56}$ Ibid

${ }^{57}$ Eva Achjani Zulfa, Op. Cit., hlm. 40
} 
mandatory sentence merupakan mekanisme penjatuhan sanksi pidana yang ditentukan oleh UU berdasarkan skala tertentu biasanya ditentukan oleh skala minimal lamanya pidana yang harus dijalani pelakunya. Pemidanaan dengan menggunakan mekanisme ini berdampak pada berkurangnya sentencing dicretion para hakim. Pendekatan matematis dapat juga menghasilkan kepastian hukum (menghukum lebih konsisten) bagi para terdakwa terkait dengan pejatuhan hukuman penjara sebagai hukuman pengganti bagi para terdakwa yang akan mereduksi terjadinya disparitas hukuman. Disparitas hukuman akan menjadi perhatian bagi para pembuat undang-undang dan perencanaan pembuat undangundang di manca negara. ${ }^{58}$

Pengenaan suku bunga terhadap penggantian kerugian negara karena dana yang dikorupsi oleh terdakwa memiliki nilai ekonomis jika pada waktu tertentu dana tersebut diinvestasikan dalam produk keuangan. Pemikiran tersebut merupakan pemikiran yang logis seperti yang diutarakan oleh Prof Jeremy Horber dalam interview yang dilakukan oleh peneliti di London School of Economic, London, UK.59 Horber selanjutnya mengatakan bahwa di Inggris penanganan pengembalian aset negara lebih tinggi kesuksesannya terhadap pelanggaran dengan skala ringan ketimbang pelanggaran skala yang lebih besar atau dengan kata lain skala pelanggaran ringan lebih mudah penanganannya. ${ }^{60}$

Pengembalian kerugian negara lebih utama daripada mengenakan denda kepada terdakwa dalam pengadilan di Inggris. Penjatuhan pidana denda merupakan bagian dari pidana pokok yang tercantum dalam Pasal 2 UU Tipikor di Indonesia.

Peneliti sebagai praktisi di bidang penegakan hukum Tipikor menerapkan ide tulisan ini dalam membuat putusan pasca penelitian ataupun pra penelitian. Beberapa putusan yang telah diterapkan mengenai proporsionalitas pengganti pidana uang pengganti adalah sebagai berikut:

1. Putusan Pengadilan Tinggi Jawa Barat Nomor 26/TIPIKOR/2013/PT.BDG tanggal 22 Juli 2013 yang pada amar putusan nomor 7 disebutkan Menghukum hlm. 31

${ }^{58}$ Martin L. Frost, Sentencing Reform: Experiments in Reducing Disparity, Sage Publication, California, 1982,

${ }_{59}$ Direct Closing InterviewProf John Horber, Lecturer of Criminal Law, London School of Economic, England, 24 September 2014

${ }^{60}$ Ibid 
terdakwa $x x$ membayar uang pengganti sebanyak Rp... dengan ketentuan jika Terpidana dalam waktu 1 (satu) bulan sesudah putusan Pengadilan telah memperoleh kekuatan hukum tetap tidak melakukan pembayaran uang pengganti, maka harta bendanya dapat disita oleh Jaksa dan dilelang untuk menutupi uang pengganti tersebut, dan dalam hal Terpidana tidak mempunyai harta benda yang mencukupi untuk membayar uang pengganti tersebut, maka dipidana dengan pidana penjara selama ... tahun. Dalam hal Terpidana/Terpidana lain yang terbukti secara bersama-sama melakukan Tindak Pidana Korupsi telah membayar uang pengganti baik bersumber dari hasil penjualan harta benda Terdakwa atau pembayaran langsung, maka jumlah total uang yang telah dibayarkan akan diperhitungkan secara proporsional sebagai pengurangan terhadap lamanya pidana penjara yang telah dijatuhkan. Pertimbangan pada amar putusan ini disebutkan bahwa dengan pertimbangan dari aspek keadilan yang berbunyi "bahwa dirasakan tidak adil apabila terpidana dikemudian hari telah membayar uang pengganti akan tetapi tidak mencukupi seluruh jumlah uang pengganti yang harus dibayar yaitu Rp ..., tetap dipidana dengan pidana penjara selama .... Tahun" dan pertimbangan lainnya yang berbunyi "demi mendorong pembayaran uang pengganti dengan maksud memulihkan keuangan Negara, dengan ditambahkannya kalimat tersebut maka tercipta kepastian hukum bahwa Terdakwa akan menerima pengurangan pidana penjara secara proporsional atas pembayaran yang telah dilakukan. Hal ini dimaksudkan akan mendorong Terpidana untuk membayar uang pengganti secara maksimal".

2. Putusan Dissenting Opinion Peneliti pada pengadilan tingkat Banding No 2/TIPIKOR/2015/PT-Bdg tertanggal 3 Maret 2015, yang mana dalam amar putusan nomor 5 disebut bahwa Menghukum Terdakwa xx membayar kerugian negara sebesar ..... rupiah dan, dengan ketentuan jika Terpidana dalam waktu 1 (satu) bulan sesudah putusan Pengadilan telah memperoleh kekuatan hukum tetap tidak melakukan pembayaran uang pengganti, maka harta bendanya dapat disita oleh Jaksa dan dilelang untuk menutupi uang pengganti tersebut, dan dalam hal Terpidana tidak mempunyai harta benda yang mencukupi untuk membayar uang pengganti tersebut, maka dipidana dengan pidana penjara selama .... tahun. Dalam hal Terpidana/Terpidana lain yang terbukti secara bersama-sama melakukan Tindak Pidana Korupsi dalam perkara ini, telah membayar uang pengganti baik bersumber dari hasil penjualan harta benda Terdakwa atau pembayaran langsung, maka jumlah total uang yang telah dibayarkan akan diperhitungkan secara proporsional sebagai pengurangan terhadap pengganti pidana uang pengganti.

Perkembangan atas ide perhitungan pengganti pidana uang pengganti dalam praktiknya diajukan oleh jaksa penuntut umum pada tuntutan dalam perkara pengadilan tingkat pertama tipikor Bandung, Jawa Barat Nomor: 96/PID.SUS/TPK/2014/PN.Bdg. tertanggal 14 januari 2015, yang disebutkan dalam tuntutan pada angka 4 yaitu menetapkan agar pidana penjara subsidiair uang pengganti yang akan dijalani oleh terdakwa $x x$ diperhitungkan secara persentase dengan pengembalian kerugian negara baik yang dibayar sendiri secara sukarela oleh terdakwa $\mathrm{xx}$, diperoleh dari pelelangan harta kekayaan 
miliknya oleh negara, dibayar oleh pihak lain yang berkaitan dengan aliran dana hibah atau pun yang menjadi tanggungjawab pihak lain sebagai terpidana berdasarkan putusan hakim yang berkekuatan tetap. Putusan Nomor: 96/PID.SUS/TPK/2014/PN.Bdg tersebut telah dimintakan Banding ke pengadilan Tinggi Tipikor Jawa Barat, yang akhirnya Pengadilan Tinggi Tipikor dalam amar putusannya tentang penjatuhan pidana uang pengganti dalam Putusan Nomor: 5 / Tipikor / 2015 / Pt. Bdg menyebutkan bahwa menghukum Terdakwa untuk membayar uang pengganti sejumlah .... paling lama dalam waktu satu bulan sesudah putusan ini berkekuatan hukum tetap, jika tidak membayar maka harta bendanya disita dan dilelang oleh Jaksa untuk menutupi uang pengganti tersebut dengan ketentuan apabila Terpidana tidak mempunyai harta benda yang mencukupi maka dipidana dengan pidana penjara selama ... tahun. Dalam hal Terpidana lain yang terbukti secara bersama-sama melakukan Tindak Pidana Korupsi dalam perkara ini, telah membayar uang pengganti baik bersumber dari hasil penjualan harta benda Terdakwa atau pembayaran langsung, maka jumlah total uang yang telah dibayarkan akan diperhitungkan secara proporsional sebagai pengurangan terhadap pengganti pidana uang pengganti.

Beberapa aspek yang disuarakan oleh pegiat anti korupsi yang telah diatur oleh UU seperti restorative justice akan terwujud seiring dengan penerapan konsep proporsionalitas dan kesebandingan termasuk disparitas yang tidak lebar pada pengganti pidana uang pengganti berupa tambahan hukuman penjara atas ketidakmampuan terpidana mengembalikan uang negara.

Pencegahan dalam konteks peradilan pidana adalah menghindari kejahatan yang potensial melalui rasa takut akan akibatnya dari kejahatan tersebut. Pencegahan yang umum mengacu pada dampak terhadap pelaku yang potensial dari beberapa aspek dari sistem peradilan pidana. Pencegahan secara khusus sebaliknya mengacu pada dampak pencegahan kepada para pelaku yang sedang ditangani oleh sistem peradilan pidana pada kondisi tertentu. ${ }^{61}$ Aspek kunci dari hukuman adalah adil dan efektivitasnya, karena hukuman menyebabkan menimbulkan kesengsaraan/penderitaan dan masalah keadilan yang bersangkutan. ${ }^{6}$

Hal yang terjelas dalam level tertentu dari pemilihan sanksi adalah terdapatnya perbedaan berbagai pengukuran yang diadopsi dari suatu perkara.

\footnotetext{
61 Anthony Bottoms, Empirical Research Relevant to Sentencing Framworks (Alternative to Prison edited by Anthony Bottoms, Sue Rex, Gwen Robinson), First Published, Willan Publishing, UK, 2004, hlm. 63

${ }^{62}$ Francis Pakes, Op. Cit., No Page.
} 
Secara khusus dalam perspektif hukum, beberapa sanksi mempertimbangan berbagai ukuran seperti kompensasi, penyitaan aset dan rentang hukuman yang biasanya diterapkan pada aset pelaku pelanggar hukum. ${ }^{63}$

Keragaman pendapat mengenai hukuman, terungkap dalam penelitian menunjukkan hal yang tak terduga dalam sikap umum masyarakat tentang hukuman atas kejahatan, sejumlah besar orang Australia menyarankan alternatif non-penahanan penjara berupa hukuman denda, hukuman percobaan dan pelayanan kepada masyarakat. Kompleksitas proses penghukuman sering diakui oleh pemberitaan di tabloid, koran, dan diakui oleh masyarakat luas. ${ }^{64}$ Tujuan dari hukuman denda itu sendiri tidak sulit untuk menemukan alasan bagi penegak hukum untuk memilih hukuman denda tersebut. Hukuman denda adalah hukuman yang tegas, yang mana dirancang untuk pencegahan yang signifikan pada saat ini, dimana pemulihan dalam kondisi yang ideal telah memudar. 65

\section{Penutup}

Pertama, pembayaran uang pengganti dalam praktik tidak melindungi hak ekonomis masyarakat yang hilang dengan berjalannya waktu sampai dengan putusan berkekuatan hukum tetap, pembayaran uang pengganti hanya didasarkan pada jumlah yang diperoleh terdakwa hasil tindak pidana korupsi. Kedua, konsep kesebandingan/proporsionalitas pengganti pidana uang pengganti dapat diterapkan dengan pendekatan Jurimetri.

Rekomendasi peneliti antara lain: pertama, pembayaran pidana uang pengganti harus memperhitungkan elemen suku bunga (time value of money), dengan maksud memperhitungkan kompensasi nilai ekonomis negara yang hilang seiring dengan berjalannya waktu. Kedua, penegak hukum dapat menggunakan konsep jurimetri berupa pedoman/petunjuk pengganti pidana

63 Christopher Harding, Criminal Enterprise Individuals, Organisations and Criminal Responsibility, First Published, Willan Publshing, USA, 2007, hlm. 114

${ }^{64}$ John Walker, Mark Collins, Paul Wilson, How The Public Sees Sentencing: an Australian Survey(Public Attitudes to Sentencing edited by Nigel Walker, Mike Hough),Gower Publishing Company Limited, USA, 1988, hlm. 159

${ }^{65}$ Sally T. Hillsman, Joyce L. Sichel, Barry Mahoney, Fines in Sentencing a Study of The Use of The Fine as a Criminal Sanction, The Vera Institute of Justice, New York, USA, Nov 1984, hlm. 21. 
uang pengganti sesuai dengan porsi pengembalian kerugian negara untuk menghindari disparitas yang lebar dalam hal menentukan pengganti pidana uang pengganti.

\section{Daftar Pustaka}

Achjani Zulfa, Eva, Pergeseran Paradigma Pemidanaan, Cetakan ke 1, Lubuk Agung, Bandung 2011.

Alwi, Syafaruddin, Alat-alat Analisis dalam Pembelanjaan, Andi Offset Yogyakarta, Edisi Revisi, Yogyakarta, 1994.

Ashworth, Andrew, Is Restorative Justice The Way Forward for Criminal Justice (Restorative Justice Critical Issues Edited by Eugene McLaughlin, Ross Fergusson, Gordon Hughes, Louise Westmarland), First Published, Sage Publication, London, 2003.

, Sentencing and Criminal Justice, Cambridge University Press, Fifth Edition, UK, 2010.

Bagaric, Mirko, Punishment and Sentencing a Rational Approach, First Published, Cavendish Publishing Limited, Unite Kongdom, 2001.

Bakhri, Syaiful, Perkembangan Stelsel Pidana Indonesia, Cetakan 1, Total Media, Yogyakarta, Oktober 2009.

Barak, Aharok, Judicial Discretion, Yale University Press, USA,1987.

Black, Henry, Campbell, Black Law Dictionary, West Group, USA, 1991.

Bottoms, Anthony Empirical Research Relevant to Sentencing Framworks (Alternative to Prison edited by Anthony Bottoms, Sue Rex, Gwen Robinson), First Published, Willan Publishing, UK, 2004.

Brigham \& Houston, Fundamentals of Financial Management, Dasar-Dasar Manajemen Keuangan, Buku 1, Edisi 10, Salemba Empat, Jakarta, 2004.

C. Higgins, Robert, Analisis Manajemen Keuangan, Edisi Kedua, Indira, 1996.

Feinberg, Joel, The Expressive Function of Punishment, State University of New York Page, Albany 1972.

Garland, David, Punishment and Modern Society, The University of Chicago Press, USA, 1990.

Gross, Hyman, Crime and Punishment, Oxford University Press, Newyork, 2012.

Hanitijo, Ronny, Metode Penelitian Hukum dan Jurimetri, Cetakan Keempat, Ghalia Indonesia, Jakarta, 1990.

Harding, Christopher Criminal Enterprise Individuals, Organisations And Criminal Responsibility, First Published, Willan Publshing, USA, 2007. 
Honderich, Ted, Punishment, The Supposed Justifications, Cambridge,USA, 1989.

Hudson, Barbara Justice Through Punishment, First Published, Macmillan Education, London, 1987.

Huesmann, L.R. and C.L. Podolski, Punishment:a Psychological Perspective(The Use of Punisment edited by Sean McConville), First Published, Willan Publishing, Oregon, USA, 2003.

J. Rizzo, Mario, Economic Cost, Moral Costs or Retributive, The Cost of Crime (editor Charles M. Gray), Volume 12, Sage Publication, Inc, Londong, England, 1979.

L. Frost, Martin, Sentencing Reform: Experiments in Reducing Disparity, Sage Publication, California, 1982.

Laila Kholis, Efi, Pembayaran Uang Pengganti Dalam Perkara Korupsi, Cetakan Pertama, Solusi Publishing, Jakarta, April 2010.

Lovegrove, Austin Judicial Decision Making, Sentencing Policy, and Numerical Guidance, R.R. Donnelley \& Sons, Melbourne, Australia, 1989.

M. Ward, Peter, Corruption Development and Inequality, First Published, Routledge, London, 1989.

Manson, Allan, The Law of Sentencing, Irwin Law, Toronto, 2001.

Martono, D. Agus Harjito, Manajemen Keuangan, Cetakan kedelapan, Ekonisa, Yogyakarta, juni 2010.

Nawawi, Barda Bunga Rampai Kebijakan Hukum Pidana, Cetakan Ketiga Edisi Revisi, Citra Aditya Bakti, Bandung, 2005.

Neild, Robert, Public Corruption the Dark Side of Social Evolution, First Published, Anthem Press, London, 2002.

Notohamidjodjo, O., Makna Negara Hukum Bagi Pembaharuan Negara dan Wibawa Hukum Bagi Pembaharuan Masyarakat Indonesia, Badan Penerbit Kristen, Jakarta, Oktober 1967.

Oppenheimer, Heinrich, The Rationale of Punishment, Univesity London Press, 1913.

P. Gibbs, Jack, Crime Punishment and Deterrence, Elsevier Scientific Publishing Company, Inc, New York, 1975.

Pakes, Francis, Comparative Criminal Justice, Willan Publishing, USA, 2004.

Panjaitan, Irwan, Petrus Chairijah, Pidana Penjara Dalam Perspektif Penegak Hukum Masyarakat dan Narapidana, Terbitan Pertama, Jakarta, 2008.

Priyatno, Dwidja, Sistem Pelaksanaan Pidana Penjara di Indonesia,Cetakan Kedua, Refika Aditama, Bandung, Oktober 2009.

Setiadi, Edi, Rena Yulia, Hukum Pidana Ekonomi, Graha Ilmu, Edisi Pertama, Cetakan Pertama, Yogyakarta, 2010. 
Supanto, Kejahatan Ekonomi Global dan Kebijakan Hukum Pidana, Cetakan Pertama, Edisi Pertama Alumni, Bandung, 2010.

T. Hillsman, Sally, Joyce L. Sichel, Barry Mahoney, Fines In Sentencing a Study of The Use of The Fine as a Criminal Sanction, The Vera Institute of Justice, New York, USA, Nov 1984.

Tonry, Michael, Judges and Sentencing Policy (Sentencing, Judicial Discretion and Training edited by Colin Munro, Martin Wasik), Sweet \& Maxwell, London 1992.

V. Roberts, Julian, Sentencing Trends and Sentencing Disparity (Making sense of sentencing edited by Julian V. Roberts and David P. Cole, University of Toronto Press, Canada 1999.

von Hirsch, Andrew \& Andrew Ashworth, Proportionate Sentencing Eploring the Principles, First Published, Oxford University Press, New York, October 2005.

W. Ireland, Richard, Punishment Rhetoric, Rule, and Practise, First Published, Routledge, New York, USA

Walker, John, Mark Collins, Paul Wilson, How The Public Sees Sentencing: an Australian Survey (Public Attitudes to Sentencing edited by Nigel Walker, Mike Hough),Gower Publishing Company Limited, USA, 1988.

Walker, Nigel, Nicola Padfield, Sentencing Theory, Law and Practise, Butterworths, Second Edition, London, Dublin \& Ediburgh, 1996.

Willemsens, Jolien, Restorative Justice: A Discussion Of Punishment (Repostioning Restorative Justice edited by Lode Walgrave), First Published Willan Publsihing Culmcott House, UK 2003.

Black Law Dictionary, New Edition (Ninth Edition by Bryan A. Garner),West, Publishing Co,USA, 2004.

UUD Negara RI Tahun 1945

UU No. 31 Tahun 1999 sebagaimana telah diubah dengan UU 20 Tahun 2001 Tentang Tipikor. 